\title{
Unusual neurologic presentation of aseptic abscesses syndrome
}

Philippe Nicolas, MD, * Olivier Guerrier, MD,* Amandine Benoit, MD, Francoise Durand-Dubief, MD, Gerald Raverot, MD, PhD, Sebastien Debarbieux, MD, Clemence Delteil, MD, Alexandre Vasiljevic, MD, Emmanuel Jouanneau, MD, PhD, Francois Cotton, MD, PhD, Romain Marignier, MD, PhD, and Sandra Vukusic, MD, PhD

Neurol Neuroimmunol Neuroinflamm 2018;5:e469. doi:10.1212/NXI.0000000000000469
Correspondence

Philippe Nicolas

philippe.nicolas01@gmail.com

\section{Clinical case}

A 25-year-old woman of North African origin, with no personal or family history, successively developed noninfectious abscess-like formations involving multiple organs including the CNS.

First, she developed large pustular and ulcerative skin lesions evocative of pyoderma gangrenosum (PG) (figure, A and B) with hyperthermia up to $38.5^{\circ} \mathrm{C}$. Skin biopsies revealed a sterile nonfollicular neutrophilic infiltration of the dermis (figure, $\mathrm{C}$ and $\mathrm{D}$ ), supporting this diagnosis. Blood samples showed an inflammatory reaction, but all infectious explorations were negative. A chest-abdomen-pelvis CT scan revealed numerous nodular splenic formations (figure, E). Corticosteroids ( $1 \mathrm{mg} / \mathrm{kg} / \mathrm{d}$ ) were initiated for the treatment of PG, and the patient rapidly improved with healing of the cutaneous lesions and regression of the splenic abscesses (figure, F).

Seven months later, she presented with meningeal syndrome with hyperthermia. Brain MRI was normal. CSF analysis revealed meningitis with 800 leukocytes (90\% neutrophils) and hypoglycorrhachia at $1.5 \mathrm{mmol} / \mathrm{L}$, but which was sterile with a negative universal PCR. The diagnosis of aseptic meningitis was considered. Nonetheless, the patient was treated with amoxicillin, cefotaxime, and dexamethasone for 10 days with a spectacular improvement after 24 hours.

Six months later, she presented with progressively worsening headache associated with spatiotemporal disorientation and hyperthermia. Brain MRI revealed hydrocephalus secondary to a voluminous gadolinium-enhancing hypothalamic-pituitary multiloculated lesion (figure, G). The endocrinologic workup showed global pituitary insufficiency requiring supplementation by hydrocortisone, levothyroxine, and sex hormones. CSF analysis revealed pleocytosis with 90 leukocytes $/ \mathrm{mm}^{3}$ (75\% lymphocytes), an increased IgG index (0.77), and oligoclonal bands. Direct microbiologic analyses and cultures were negative in blood and CSF, including mycobacteria. The QuantiFERON ${ }^{\circledR}$-TB test was negative. A transsphenoidal biopsy of the pituitary lesion highlighted multiple microabscesses infiltrating and destroying the normal anterior pituitary tissue. Microabscesses were characterized by a central area of necrotic debris and neutrophils surrounded by a chronic inflammatory infiltrate of plasma cells and macrophages; there was no granuloma (figure, I-K). Cultures were sterile, and the universal and mycobacteria

*These authors contributed equally to the manuscript.

From the Service de Neurologie, sclérose en plaques (P.N., O.G., A.B., F.D.-D., R.M., S.V.), pathologies de la myéline et neuro-inflammation, Hôpital Neurologique Pierre Wertheimer, Hospices Civils de Lyon, Bron; Centre des Neurosciences de Lyon (A.V., R.M.), INSERM 1028 et CNRS UMR5292, Equipe FLUID et Observatoire Français de la Sclérose en Plaques; Université de Lyon (A.V., R.M.); INSERM U1052 (G.R., E.J.), CNRS UMR5286, Cancer Research Center of Lyon; Fédération d'Endocrinologie (G.R., E.J.), Groupement Hospitalier Est, Hospices Civils de Lyon, Bron; Service de Radiologie (F.C.), Centre Hospitalier Lyon-Sud, Hospices Civils de Lyon, Université Claude Bernard Lyon1, Université de Lyon, Pierre Bénite; CREATIS (F.D.-D., F.C.), UMR 5220 CNRS \& U1044 Inserm, Université Claude Bernard Lyon1, Université de Lyon, Villeurbanne; Service d'anatomie et cytologie pathologiques (C.D.), Centre Hospitalier de la Timone, France; Centre de Pathologie et Neuropathologie Est (A.V.), Groupement Hospitalier Est, Hospices Civils de Lyon, Bron; Service de dermatologie (S.D.), Centre Hospitalier Lyon Sud, 69495 Pierre Bénite; and Service de Neurochirurgie B (E.J.), Hôpital Neurologique Pierre Wertheimer, Hospices Civils de Lyon, Bron, France.

Funding information and disclosures are provided at the end of the article. Full disclosure form information provided by the authors is available with the full text of this article at Neurology.org/NN.

The Article Processing Charge was funded by the authors.

This is an open access article distributed under the terms of the Creative Commons Attribution-NonCommercial-NoDerivatives License 4.0 (CC BY-NC-ND), which permits downloading and sharing the work provided it is properly cited. The work cannot be changed in any way or used commercially without permission from the journal. 
Figure Skin, spleen, and hypothalamic-pituitary lesions
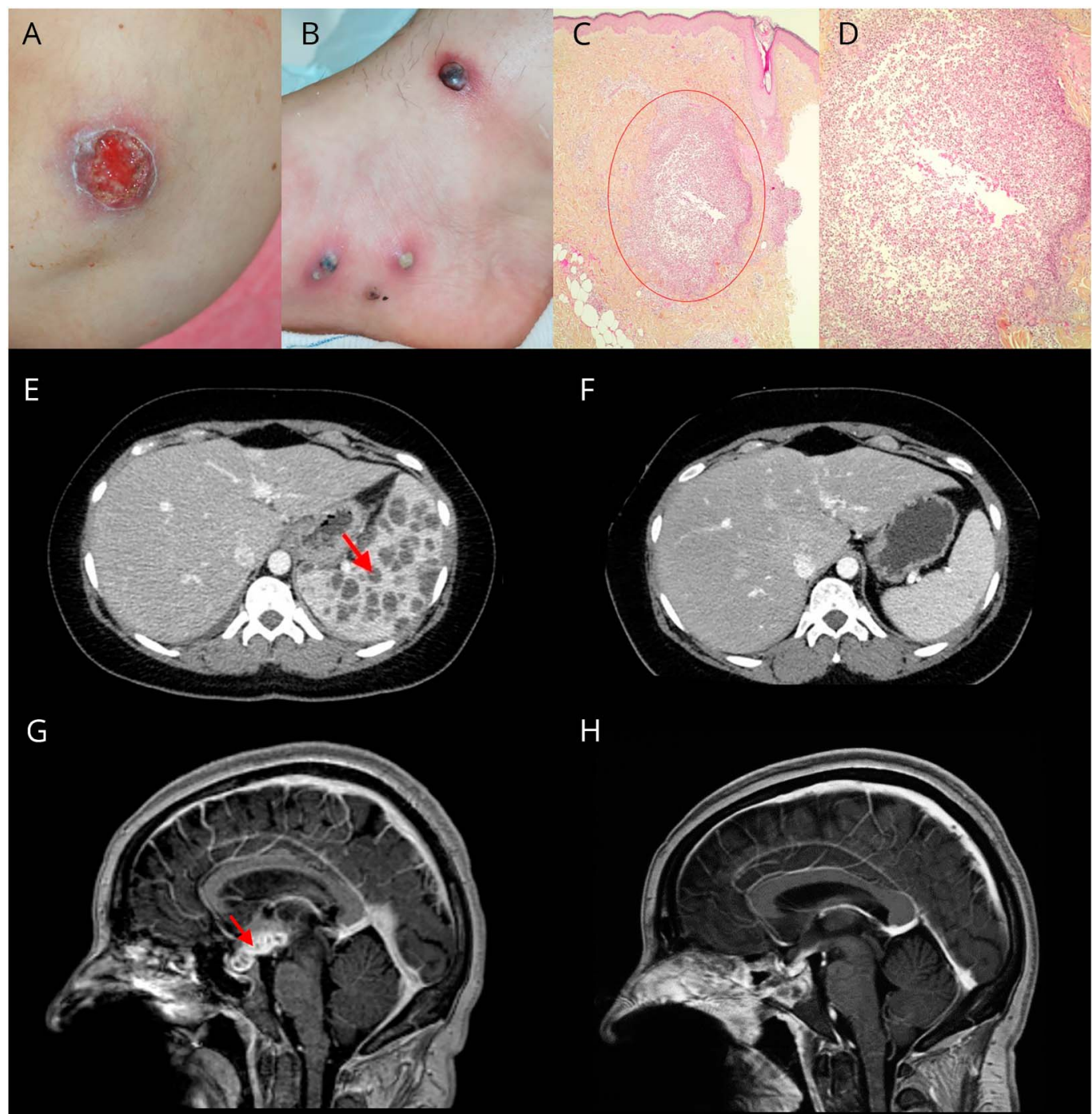

$\mathrm{H}$

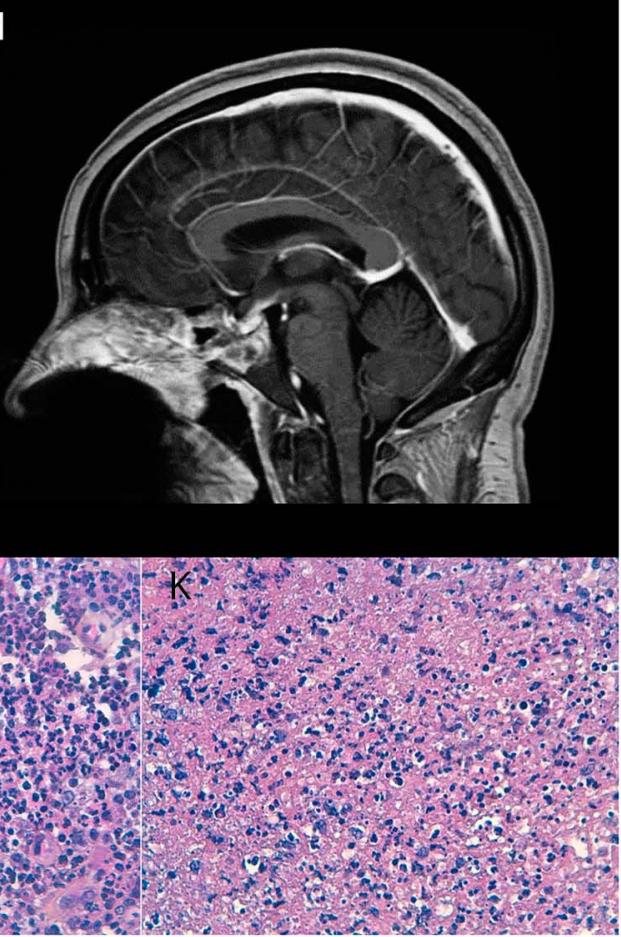

(A-D) Skin lesions: pyoderma gangrenosum (PG)-like ulceration of the elbow (A) and large pustules on the ankle surrounded by an inflammatory basis (B). Histopathologic aspect (courtesy of Dr. B. Balme Centre Hospitalier Lyon Sud) showing a dermal neutrophilic abscess (red circle). HES (hematoxylin, eosin saffron) staining. Original magnification $\times 4$ (C) and original magnification $\times 10$ (D). (E and F) Spleen lesions: contrast-enhanced abdominal CT showing splenomegaly related to numerous splenic abscesses (red arrow) (E). Disappearance of the splenic abscesses after steroid treatment (F). (G-K) Hypothalamicpituitary lesion. (G) Brain MRI: sequential contrast-enhanced sagittal T1-weighted images showing a voluminous $(31 \mathrm{~mm} / 17 \mathrm{~mm} / 13 \mathrm{~mm})$ gadoliniumenhancing hypothalamic-pituitary multiloculated lesion (red arrow). (H) Spontaneous vanishing of the hypothalamic-pituitary lesion. (I-K) Pituitary histopathology showing microabscesses (l; black arrow) composed of numerous neutrophils (l; arrowhead) and necrotic debris (K). Original magnification $\times 100(\mathrm{I})$ and $\times 400(\mathrm{I}$ and K). Special histochemical stains (Gram, Grocott, PAS [Periodic acid-Schiff], and Ziehl) did not detect any bacteria, fungi, or mycobacteria. Universal and mycobacteria PCR were negative. Standard, parasite, and fungal cultures were sterile.

PCR were negative. Remarkably, the patient spontaneously improved with the disappearance of disorientation and headaches and vanishing of the multiloculated lesion (figure,
$\mathrm{H}$ ), without any specific treatment except substitutive hormonal replacement; hydrocortisone is not believed to have anti-inflammatory properties at this dose. 
The initially considered diagnoses were ruled out. First, microbiologic investigations, including mycobacteria, were not suggestive of a septic origin. Second, clinical examination and biological, radiologic, and neuropathologic features were not supportive of sarcoidosis-no granuloma-Behcet disease, and histiocytosis. Finally, there was no evidence of malignancy, including lymphoma to date, nor immunodeficiency.

\section{Discussion}

In the light of the remarkable history of multiple abscess-like lesions, involving the skin, spleen, meninges and CNS, the extensive microbiologic workup that remained negative, the histopathologic features, and the corticosensitivity, we finally settled on the diagnosis of aseptic abscesses (AA) syndrome. We did not perform genetic explorations, and therefore, we cannot exclude the possibility of an associated monogenic autoinflammatory disorder or immunodeficiency syndrome.

AA is a rare autoinflammatory disease mainly affecting young adults. It is characterized by recurrent attacks of fever and deep round aseptic lesions potentially involving all organs. ${ }^{1} \mathrm{~A}$ neutrophilic dermatosis, such as PG, may be associated. ${ }^{1,2}$ Extensive microbiologic workups remain negative, and antibiotics fail to cure patients but relapses can be prevented by corticosteroids and immunosuppressive drugs such as TNF- $\alpha$ antagonists or IL-1 receptor antagonists. ${ }^{1,3}$ There is no specific feature to distinguish a septic from an aseptic abscess on MRI, although it would be helpful in establishing the diagnosis and eventually preventing the need for biopsies.

The pathophysiology of AA remains unknown but seems to be a multifactorial combination of neutrophil dysfunction, inflammation, and genetic predisposition. ${ }^{2,4,5}$ AA shares some features with other entities such as pyogenic arthritis, pyoderma gangrenosum, and acne syndrome-a monogenic autoinflammatory disorder characterized by PG, acne, and pyogenic sterile arthritis-Behçet disease, and neutrophilic dermatosis such as PG or Sweet syndrome. Neurologic involvement in those neutrophilic diseases has already been described in $\mathrm{BD}^{6}$ and in SS.7 These entities widely overlap with AA, sharing features including a neutrophilic infiltrate, a high incidence of aseptic splenic abscesses, and corticosensitivity. The clinical and radiologic presentations were not supportive of neuro-Behcet and we decided to retain the diagnosis of AA because the diagnostic criteria for neuro-Sweet ${ }^{7}$ were not fulfilled, although there is a continuum between PG, SS, and AA.

In conclusion, our case emphasizes the possibility of CNS involvement of AA syndrome and highlights the need of an early diagnosis to rapidly start an appropriate treatment.

\section{Author contributions}

Data collection: P. Nicolas, O. Guerrier, A. Benoit, G. Raverot, S. Debarbieux, and F. Cotton. Data analysis and interpretation:
P. Nicolas, O.Guerrier, A. Benoit, F. Durand-Dubief, G. Raverot, S. Debarbieux, C. Delteil, A. Vasiljevic, E. Jouanneau, F. Cotton, R. Marignier, and S. Vukusic. Literature search: P. Nicolas, O.Guerrier, and A. Benoit. Figures: P. Nicolas, G. Raverot, S. Debarbieux, C. Delteil, A. Vasiljevic, and F. Cotton. Drafting the article: P. Nicolas, O.Guerrier, R. Marignier, and S. Vukusic. Critical revision of the manuscript: A. Benoit, F. Durand-Dubief, G. Raverot, S. Debarbieux, C. Delteil, A. Vasiljevic, E. Jouanneau, and F. Cotton. Final approval of the version to be published: P. Nicolas, O. Guerrier, A. Benoit, F. Durand-Dubief, G. Raverot, S. Debarbieux, C. Delteil, A. Vasiljevic, E. Jouanneau, F. Cotton, R. Marignier, and S. Vukusic. P. Nicolas and O. Guerrier have contributed equally to the manuscript.

\section{Study funding}

No targeted funding reported.

\section{Disclosure}

P. Nicolas, O. Guerrier, and A. Benoit report no disclosures. F. Durand-Dubief served on the scientific advisory board of Roche and Merck Serono and received travel funding and/or speaker honoraria from Biogen, Merck Serono, SanofiAventis, Novartis Pharma, and Roche. G. Raerot, S. Debarbieux, C. Delteil, A. Vasiljevic, E. Jouanneau, and F. Cotton report no disclosures. R. Marignier served on the scientific advisory board of MedImmune and received speaker honoraria and travel funding from Biogen Idec, Genzyme, Novartis, Merck Serono, Roche, Sanofi-Aventis, and Teva. S. Vukusic served on the scientific advisory board of Biogen Idec, Celgene, Geneuro, Genzyme, Merck Serono, Novartis Pharma, Roche, Sanofi-Aventis, and Teva; received travel funding and/ or speaker honoraria from Biogen Idec, Genzyme, Merck Serono, Novartis, Roche, Sanofi-Aventis, and Teva Pharma; consulted for Biogen Idec, Celgene, Geneuro, Genzyme, Merck Serono, Novartis, Roche, Sanofi-Aventis, and Teva; and received research support from Biogen Idec, Genzyme, Medday, Merck Serono, Novartis, Roche, Sanofi-Aventis, and Teva. Full disclosure form information provided by the authors is available with the full text of this article at Neurology.org/NN.

Received February 12, 2018. Accepted in final form April 23, 2018.

\section{References}

1. André MF, Piette JC, Kémény JL, et al. Aseptic abscesses: a study of 30 patients with or without inflammatory bowel disease and review of the literature. Medicine (Baltimore) 2007;86:145-161.

2. Wallach D, Vignon-Pennamen MD. From acute febrile neutrophilic dermatosis to neutrophilic disease: forty years of clinical research. J Am Acad Dermatol 2006;55:1066-1071. Bardy A, Guettrot-Imbert G, Aumaître O, André MF. Efficacy of Il-1 $\beta$ blockade in refractory aseptic abscesses syndrome. Mod Rheumatol 2014;24:217-219.

4. André MF, Aumaître O, Grateau G, et al. Longest form of CCTG microsatellite repeat in the promoter of the CD2BP1/PSTPIP1 gene is associated with aseptic abscesses and with Crohn disease in French patients. Dig Dis Sci 2010;55:1681-1688.

5. Braswell SF, Kostopoulos TC, Ortega-Loayza AG. Pathophysiology of pyoderma gangrenosum (PG): an updated review. J Am Acad Dermatol 2015;73:691-698.

6. Hisanaga K. Neuro-neutrophilic disease: neuro-Behçet disease and neuro-Sweet disease. Intern Med 2007;46:153-154

7. Hisanaga K, Iwasaki Y, Itoyama Y; Neuro-Sweet Disease Study Group. Neuro-Sweet disease: clinical manifestations and criteria for diagnosis. Neurology 2005;24: $1756-1761$. 


\section{Neurology \\ Neuroimmunology \& Neuroinflammation}

Unusual neurologic presentation of aseptic abscesses syndrome

Philippe Nicolas, Olivier Guerrier, Amandine Benoit, et al.

Neurol Neuroimmunol Neuroinflamm 2018;5;

DOI 10.1212/NXI.0000000000000469

This information is current as of June 5, 2018

\section{Updated Information \& Services}

References

Subspecialty Collections

Permissions \& Licensing

Reprints including high resolution figures, can be found at:

http://nn.neurology.org/content/5/4/e469.full.html

This article cites 7 articles, 0 of which you can access for free at: http://nn.neurology.org/content/5/4/e469.full.html\#\#ref-list-1

This article, along with others on similar topics, appears in the following collection(s):

Abscess

http://nn.neurology.org//cgi/collection/abscess

All Clinical Neurology

http://nn.neurology.org//cgi/collection/all_clinical_neurology

All Immunology

http://nn.neurology.org//cgi/collection/all_immunology

Neuroendocrinology

http://nn.neurology.org//cgi/collection/neuroendocrinology

Information about reproducing this article in parts (figures,tables) or in its entirety can be found online at:

http://nn.neurology.org/misc/about.xhtml\#permissions

Information about ordering reprints can be found online:

http://nn.neurology.org/misc/addir.xhtml\#reprintsus

Neurol Neuroimmunol Neuroinflamm is an official journal of the American Academy of Neurology.

Published since April 2014, it is an open-access, online-only, continuous publication journal. Copyright

Copyright $\odot 2018$ The Author(s). Published by Wolters Kluwer Health, Inc. on behalf of the American

Academy of Neurology.. All rights reserved. Online ISSN: 2332-7812.

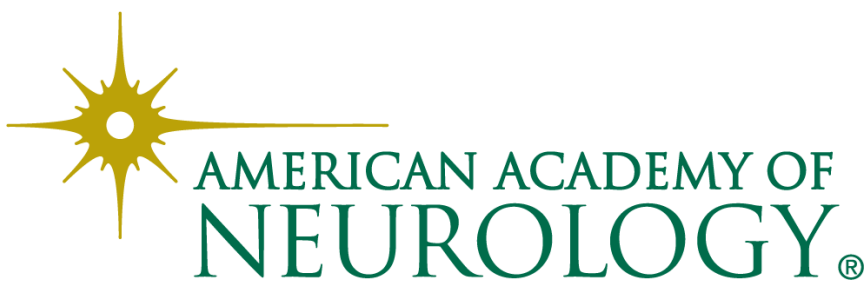

